\title{
Overexpression of Interleukin 2 Receptor, Thymidine Kinase and Immunoglobulin- Associated Alpha-1 Messenger RNA in a Clinical Case of Enzootic Bovine Leukosis
}

\author{
Mohammad Monir TAWFEEQ ${ }^{1,2)}$, Michihito TAGAWA ${ }^{1)}$, Yuuki ITOH $^{3)}$, Kazuya SUGIMOTO ${ }^{3)}$, \\ Yoshiyasu $\mathrm{KOBAYASHI}^{3)}$ and Hisashi INOKUMA ${ }^{1) *}$ \\ ${ }^{1)}$ Department of Clinical Veterinary Medicine, Obihiro University of Agriculture and Veterinary Medicine, Inada, Obihiro, Hokkaido \\ 080-8555, Japan \\ 2) Faculty of Veterinary Science, Kabul University, Jamal Mina Kabul, Afghanistan \\ 3) Department of Basic Veterinary Medicine, Obihiro University of Agriculture and Veterinary Medicine, Inada, Obihiro, Hokkaido \\ 080-8555, Japan
}

(Received 4 March 2012/Accepted 17 April 2012/Published online in J-STAGE 14 May 2012)

\begin{abstract}
ABSTARCT. A 49-month-old Holstein cow with anorexia, tachypnea, enlarged peripheral lymph nodes, and difficulty standing up was suspected of bovine leukosis. Hematological examination revealed lymphocytosis with the presence of neoplastic cells. Increased total lactate dehydrogenase (LDH) activity, isozymes of LDH-2 and LDH-3 activities and thymidine kinase activity were observed. Cytological findings of fine needle aspiration of subiliac lymph nodes indicated lymphosarcoma. Histopathology and antibody analysis confirmed the diagnosis of enzootic bovine leukosis, a B-cell bovine lymphoma caused by bovine leukemia virus. Gene expressions known as biomarkers of hematopoietic neoplasia in human were also examined in the present case. Increased messenger RNA expression of interleukin 2 receptor, thymidine kinase, and immunoglobulin-associated alpha-1 was observed in the case animal.

KEY WORDS: biomarker, bovine leukosis, gene expression.
\end{abstract}

doi: 10.1292/jvms.12-0100; J. Vet. Med. Sci. 74(9): 1203-1206, 2012

Bovine leukosis is one of the most common types of neoplasms detected in dairy cattle, and is generally divided into enzootic bovine leukosis (EBL) and sporadic bovine leukosis (SBL). EBL is caused by bovine leukemia virus (BLV), while the cause of SBL is unknown [1]. BLV infection is clinically silent, occurring as an aleukemic state or as persistent lymphocytosis. Approximately 5\% of animals infected with BLV develop B-cell lymphoma in various lymph nodes and organs after a long latent period [4]. Tumor cells often infiltrate many organs, including the abomasum, heart, uterus, retrobulbar space, and epidermal region of the central nervous system [21]. Therefore, clinical signs in cattle with lymphoma are generally non-specific and include weight loss, decreased appetite, and decreased productivity $[1,2]$.

Bovine lymphosarcoma can be easily identified by direct physical examination and diagnosed by cytological evaluation of swollen lymph nodes when lymphadenopathy and obvious neoplastic changes in target organ are present. However, it is more difficult to suspect and diagnose when located in more specific areas such as the spinal cord or abomasum and when lymph node enlargement and/or lymphocytosis is not evident [4]. While ultrasound-guided fine needle aspiration (FNA) or biopsy of vascular masses located in the body cavity, retrobulbar space, or heart is

\footnotetext{
*Correspondence to: Inokuma, H., Department of Clinical Veterinary Medicine, Obihiro University of Agriculture and Veterinary Medicine, Inada, Obihiro, Hokkaido 080-8555, Japan. e-mail: inokuma@obihiro.ac.jp.

(C)2012 The Japanese Society of Veterinary Science
}

helpful [4], such diagnostic tools are not always available. Serum lactate dehydrogenase (LDH) activity may be elevated in some cattle with lymphosarcoma [7], but its specificity is insufficient to confirm diagnosis [4]. Serum thymidine kinase (TK) activity was recently reported as a potential biomarker of bovine lymphosarcoma, but is not easy to determine as it requires a radioimmunoassay [17]. In humans, gene expression profiling has been used to assess biomarkers of lymphosarcoma and leukemia. For example, Wilms' tumor gene 1 (WT1) expression is considered a sensitive biomarker for monitoring residual disease in acute myeloid leukemia [18, 19]. Some other genes, including interleukin 2 receptor (IL2R), TK and immunoglobulinassociated alpha-1 (Mb1 or CD79a) genes were also known to be markers of hematopoietic neoplasia $[3,7,10]$. In the present report, we describe a clinical case of EBL, and the expression of candidate genes as potential biomarkers of lymphosarcoma was measured.

A 49-month-old Holstein cow with anorexia, tachypnea, and difficulty standing up was 1 st examined by a local veterinarian. At examination, the cow had a body temperature of $39.9^{\circ} \mathrm{C}$, heart rate of 80 beats $/ \mathrm{min}(\mathrm{bpm})$, and respiratory rate of 52 breaths/min. Despite antibiotic treatment via injection and infusion, the general condition of the cow did not improve. On day 7, enlargement of the subiliac lymph nodes was observed, and bovine leukosis was suspected. The cow was then taken to the Veterinary Teaching Hospital at Obihiro University of Agriculture and Veterinary Medicine. Depression, emaciation, and tachypnea were observed on admission. Rectal temperature, heart rate, and respiratory rate were $40.5^{\circ} \mathrm{C}, 92 \mathrm{bpm}$, and 96 breaths $/ \mathrm{min}$, respectively. Swelling of multiple peripheral lymph nodes, 


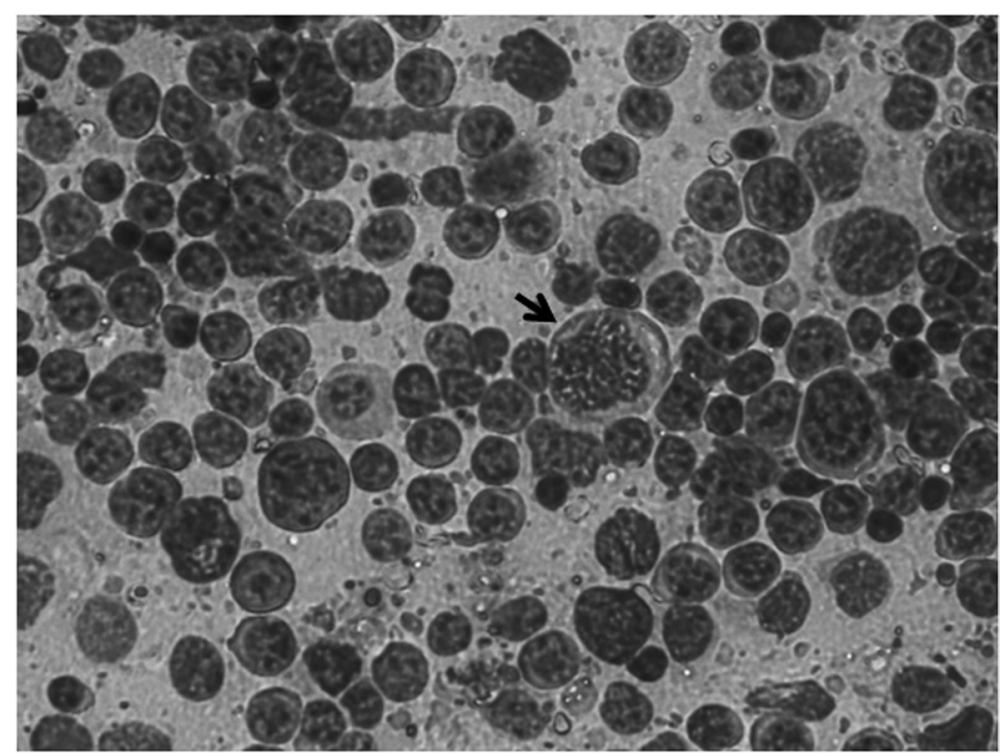

Fig. 1. Cytological finding of FNA of the right subiliac lymph node stained with a rapid dye system (Hemacolor ${ }^{\circledR}$, Merck Chemicals, Japan). The population is composed of middle to large sized lymphoid cells that have indented nuclei, finely stippled chromatin and scant amounts of cytoplasm. A mitotic cell is present in the center of the field (arrow).

including superficial cervical (R: $12 \times 7 \times 3 \mathrm{~cm}, \mathrm{~L}: 15 \times 9 \times 3$ $\mathrm{cm})$, subiliac (R: $18 \times 5 \times 3 \mathrm{~cm}, \mathrm{~L}: 12 \times 3 \times 3 \mathrm{~cm})$, mandibular ( $\mathrm{R}$ and $\mathrm{L}$ : diameter $4 \mathrm{~cm})$, and mammary lymph nodes $(\mathrm{R}$ and L: diameter $8 \mathrm{~cm}$ ) was observed. Several masses were identified in the pelvic cavity by rectal palpation. Cytological finding of FNA of the right subiliac lymph node revealed the presence of large lymphoid cells with obvious cellular atypia and several mitotic cells, indicating lymphosarcoma (Fig. 1).

Hematologic examination showed microcytic and normochromic anemia and lymphocytosis [RBC: $4.96 \times 10^{6} /$ $\mu l$, hemoglobin: $7.8 \mathrm{~g} / \mathrm{d} l$, hematocrit; $20.3 \%$, mean corpuscular volume: $43.3 \mathrm{fl}$, mean corpuscular hemoglobin: 38.4 $\mathrm{g} / \mathrm{d} l$, WBC: $107,000 / \mu l$, neutrophils: $1,070 / \mu l(1 \%)$, and lymphocytes: $105,930 / \mu l(99 \%)]$. More than $90 \%$ of lymphocytes in peripheral blood were microscopically atypical with indented nuclei and finely stippled chromatin. Serum biochemical analysis showed increased LDH activity $(2,380$ $\mathrm{IU} / l)$. LDH isozyme analysis showed elevated activities for LDH-2 (807 IU/l) and LDH-3 (455 IU/l). Serum TK activity was also measured using a commercial radioenzyme TKassay kit with ${ }^{125}$ I-iododeoxyuridine as a tracer (Kishimoto Clinical Laboratory, Inc., Obihiro, Japan). Extremely higher activities of serum TK activity (1,000 IU/l) were recorded compared with normal cattle [17]. Antibodies against BLV were detected by agar-gel immunodiffusion (Kitasato Institute Research Center for Biologicals, Saitama, Japan).

Messenger RNA (mRNA) expression of $I L 2 R, T K$ and $M b l$ in tumor tissues was examined by reverse transcription-polymerase chain reaction (RT-PCR) using the following primer sets: $5^{\prime}$ - acg-cca-tgt-tca-agg-tct-tc $-3^{\prime}$
(IL2R forward) and 5'-gtt- ctg-cgc-atc-tgt-gtg-tt -3' (IL2R reverse), 5'-cca-agt-cag-tga-tgg-caa-ga-3' (MB1 forward) and 5'-gat-atc-agc-ccc-gaa-ttt-ca-3' (MB1 reverse), and 5'-cca-ggt-tgc-cca-gta-caa-gt-3' (TK1 forward) and 5'-tctcgc-aga-act- cca-caa-tg-3' (TK1 reverse). Beta-actin gene (Actb) expression was examined as an internal control using the following primer set: $5^{\prime}$-ctt-tcc-agc-ctt-cct-tcc-t-3' (ACTB forward) and 5'-ggg-cag-tga-tct-ctt-tct-g-3' (ACTB reverse). RT-PCR was performed on swollen subiliac lymph node tissue obtained by FNA from the case animal and two healthy cows without lymphoadenopathy as controls. Total RNA was extracted using the RNeasy Mini Kit (QIAGEN, Germantown, MD, U.S.A.) according to manufacturer's instructions. cDNA was synthesized using $2 \mu \mathrm{g}$ total RNA and the SuperScript ${ }^{\mathrm{TM}}$ III 1st-strand synthesis system (Invitrogen, Carlsbad, CA, U.S.A.). Our results showed that $I L 2 R$, $T K 1$ and $M b 1$ genes were highly expressed in tumor tissue corresponding to the case compared to control cows (Fig. 2).

The cattle was euthanized and necropsy was performed on day 15. Gross examination revealed swelling of systemic lymph nodes, including superficial cervical, mandibular, mammary, medial, iliac, and renal lymph nodes. Furthermore, the spleen was enlarged and swollen $(70 \times 20 \times 8 \mathrm{~cm})$. Yellowish white tissue was found in the sternal bone marrow. Histopathological examination revealed neoplastic lymphoid cell infiltration in enlarged lymph nodes, liver, spleen, bone marrow, uterus (especially in the endometrium), and lamina propria of the urinary bladder, abdomen and intestine (Fig. 2). Immunohistochemical examination showed that tumor cells within enlarged lymph nodes were stained positive for BLA-36 and negative for CD3 antibodies (data not shown). 


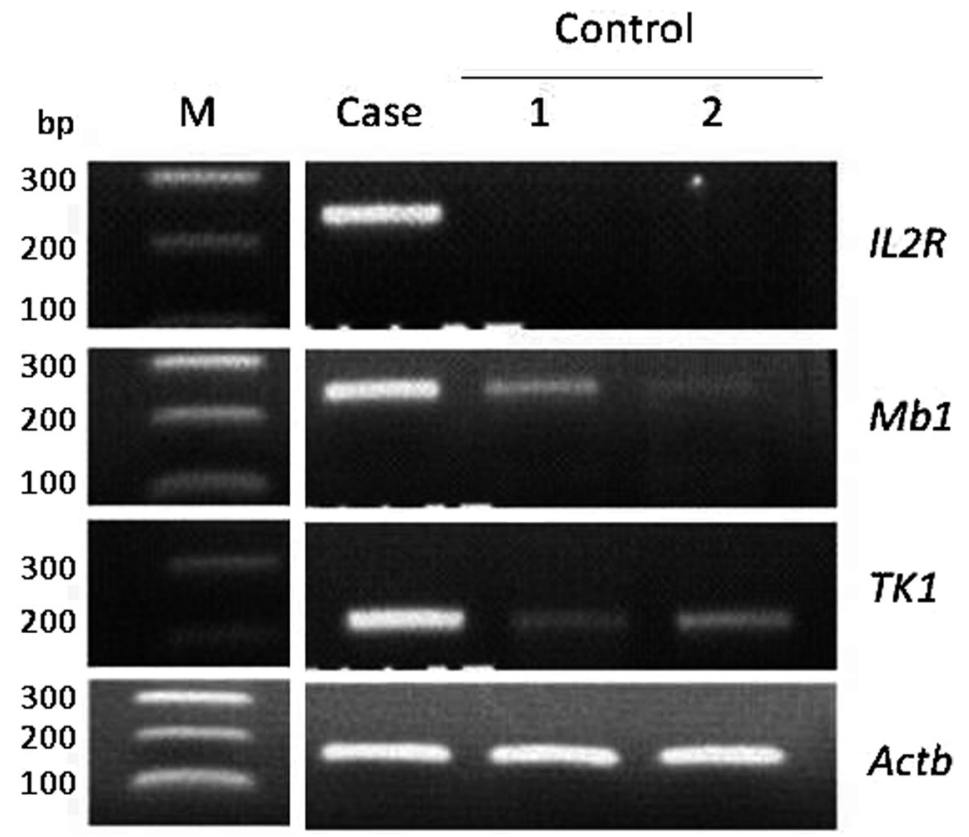

Fig. 2. Reverse transcription-polymerase chain reaction of $\operatorname{IL} 2 R(230 \mathrm{bp})$, $T K 1(203 \mathrm{bp}), \operatorname{Mbl}(214 \mathrm{bp})$, and Actb(187 bp) genes in lymph node tissues corresponding to case and control animals. $\mathrm{M}$ denotes DNA ladder.

These findings suggested that the tumor cells were B-cell origin.

In the present case, we diagnosed a 49-month-old Holstein cow with EBL, based on clinical symptoms, hematological and biochemical examinations, cytology, pathological examination, and immunohistochemical analysis. The reported biomarkers of lymphosarcoma of cattle were examined in the present case $[7,9,17]$. Higher activities of total LDH, LDH-2 and LDH-3 activities (reference range; total LDH: 692-1445, LDH-2: 187-390 IU/l and LDH-3: 10-260 IU/l) [6] were observed in the present case. We also observed extremely higher TK activity in the case animal (more than $1,000 \mathrm{IU} / l$ vs. $5.4 \mathrm{IU} / l$ ) [17]. These higher activities of both LDH and TK suggest aggressive proliferation of tumor cells in lymphoid organs and peripheral blood.

In the present study, gene expressions known as biomarkers of hematopoietic neoplasia in human were also examined. IL2R is a heterotrimeric protein expressed on the surface of immune cells, including lymphocytes and natural killer cells, and is the receptor for interleukin 2 [14, $22]$. Close association of aberrant expression of $I L 2 R$ with the infection of human T-cell leukemia virus (HTLV-1) was reported [20]. $I L 2 R$ is thought to be directly or indirectly activated by viral products, and the aberrant expression of gene might be involved in some stages of HTLV-1-infected lymphocytes [11, 24]. TK is a cellular enzyme involved in a DNA synthesis salvage pathway, and its levels have been shown to correlate directly with the proliferative activity of tumor cells $[5,8]$. Increased TK expression is often associated with increased expression of cell proliferation markers $[12,15,23]$. Both $I L 2 R$ and $T K 1$ gene overexpression have both been reported in several human leukemia cases [3, 10]; however, there are no reports available for bovine leukosis. Mbl is a well-known B-cell specific gene, and it has been reported that it is a useful marker for B-cell neoplasms in human [13]. This gene also plays a key role in B-cell development, stabilization, and function [16]. Mbl in vitro overexpression in BLV-induced bovine B-cell lines has been also reported [25]. In the present report, we observed increased expression of $I L 2 R, T K 1$, and $M b 1$ genes in the case animal compared to control cows. Increased tumor cell proliferation in neoplastic lymph nodes may contribute to the overexpression of these genes. Although only one clinical case of EBL was examined in the present study, our results underscore the use of $I L 2 R, T K 1$ and $M b 1$ gene expression as biomarkers of bovine leukosis as well as hematopoietic neoplasia in human. However, more EBL cases should be examined to confirm the validity of using the expression of these genes as biomarkers of bovine leukosis. Detail of gene expression in different stages of the disease should be also clarified by using more reliable quantitative real-time PCR in the future study.

ACKNOWLEDGMENT. We thank Dr. Noboru Kobayashi of the Tokachi Agricultural Mutual Aid Association for introducing this clinical case.

\section{REFERENCES}

1. Angelos, J. A. and Thurmond, M. C. 2008. Bovine lymphoma. pp. 1173-1176. In: Large Animal Internal Medicine, 4th ed. (Smith, B. P. ed.), Mosby Elsevier, St. Louis. 
2. Burton, A. J., Nydum, D. V., Long, E. D. and Divers, T. J. 2010. Signalment and clinical complaints initiating hospital admission, methods of diagnosis, and pathological findings associated with bovine lymphosarcoma (112 cases). J. Vet. Intern. Med. 24: 960-964. [Medline] [CrossRef]

3. Erber, W. N. and Mason, D. Y. 1988. Expression of the interleukin-2 receptor (Tac antigen/ CD25) in hematologic neoplasms. Am. J. Clin. Pathol. 89: 645-648. [Medline]

4. Garry, F. 2008. Bovine leukemia virus infection (Leukosis) (Bovine lymphosarcoma). pp 624-633. In: Rebhun's Diseases of Dairy Cattle, 2nd ed. (Divers T. J. and Peek, S. F. eds.), Saunders Elsevier, St. Louis.

5. Hallek, M., Wanders, L., Strohmeyer, S. and Emmerich, B. 1992. Thymidine kinase: a tumor marker with prognostic value for non-hodgkin's lymphoma and a broad range of potential clinical applications. Ann. Hematol. 65: 1-5. [Medline] [CrossRef]

6. Hoffman, W. E. and Solter, P. F. 2008. Diagnostic enzymology of domestic animals. pp 351-378. In: Clinical Biochemistry of Domestic Animals. 6th ed. (Kaneko J. J., Harvey, J.W. and Bruss, M. L. eds.), Academic Press, San Diego.

7. Ishihara, K., Ohtani, T., Kitagawa, H. and Onuma, M. 1980. Clinical studies on bovine leukemia in Japanese black cattle: III. Serum lactate dehydrogenase activity and its isoenzyme pattern in groups of leukemic cattle and those negative or positive for antibody against bovine leukemia virus. Jpn. J. Vet. Sci. 42: 289-295. [Medline] [CrossRef]

8. Kallender, C. F., Simonsson, B., Gronowitz, J. S. and Nilsson, K. 1987. Serum deoxythymidine kinase correlates with peripheral lymphocyte thymidine uptake in chronic lymphocytic leukemia. Eur. J. Haematol. 38: 331-337. [Medline] [CrossRef]

9. Klinkon, M. and Cerne, M. 2006. Cutaneous T-cell lymphoma in a heifer with increased serum lactate dehydrogenase activity. Vet. Clin. Pathol. 35: 231-234. [Medline] [CrossRef]

10. Kristensen, T., Jensen, H. K. and Munch-Petersen, B. 1994. Overexpression of human thymidine kinase mRNA without corresponding enzymatic activity in patients with chronic lymphatic leukemia. Leuk. Res. 18: 861-866. [Medline] [CrossRef]

11. Maeda, M., Shimizu, A., Ikuta, K., Okamoto, H., Kashihara, M., Uchiyama, T., Honjo, T. and Yodoi, J. 1985. Origin of human T-lymphotrophic virus $\mathrm{I}-$ positive $\mathrm{T}$ cell lines in adult $\mathrm{T}$ cell leukemia. Analysis of $\mathrm{T}$ cell receptor gene rearrangement. $J$. Exp. Med. 162: 2169-2174. [Medline] [CrossRef]

12. Mao, Y., Wu, J., Wang, N., He, L., Wu, C., He, Q. and Skog, S. 2002. A comparative study: immunohistochemical detection of cytosolic thymidine kinase and proliferating cell nuclear antigen in breast cancer. Cancer Invest. 20: 922-931. [Medline] [CrossRef]

13. Mason, D. Y., Cordell, J. L., Brown, M. H., Borst, J., Jones, M., Pulford, K., Jaffe, E., Ralfkiaer, E., Dallenbach, F., Stein, H., Pileri, S. and Gatter, K. C. 1995. CD79a: a novel marker for B-cell neoplasms in routinely processed tissue samples. Blood 86: 1453-1459. [Medline]
14. Nelson, B. H. and Willerford, D. M. 1998. Biology of the interleukin-2 receptor. Adv. Immunol. 70: 1-81. [Medline] [CrossRef]

15. Oudard, S., Levalois, C., Andrieu, J. M., Bougaran, J., Validire, P., Thiounn, N., Poupon, M. F., Fourme, E. and Chevillard, S. 2002. Expression of genes involved in chemoresistance, proliferation and apoptosis in clinical samples of renal cell carcinoma and correlation with clinical outcome. Anticancer Res. 22: 121-128. [Medline]

16. Pike, K. A., Iacampo, S., Friedmann, J. E. and Ritcliffe, M. J. 2004. The cytoplasmic domain of Ig alpha is necessary and sufficient to support efficient early B-cell development. J. Immunol. 172: 2210-2218. [Medline]

17. Sakamoto, L., Ohbayashi, T., Matsumoto, K., Kobayashi, Y. and Inokuma, H. 2009. Serum thymidine kinase activity as a useful marker for bovine leukosis. J. Vet. Diagn. Invest. 21: 871-874. [Medline] [CrossRef]

18. Sakamoto, Y., Mariya, Y., Sasaki, S., Teshiromori, R., Oshikiri, T., Segawa, M., Ogura, K., Akagi, T., Kubo, K., Kaimori, M. and Funato, T. 2009. WT1 mRNA level in peripheral blood is a sensitive biomarker for monitoring minimal residual disease in acute myeloid leukemia. Tohoku J. Exp. Med. 219: 169-176. [Medline] [CrossRef]

19. Siehl, J. M., Thiel, E., Leben, R., Reinwald, M., Knauf, W. and Menssen, H. D. 2002. Quantitative real-time RT-PCR detects elevated Wilms tumor gene (WT1) expression in autologous blood stem cell preparations (PBSCs) from acute myeloid leukemia (AML) patients indicating contamination with leukemic blasts. Bone Marrow Transplant. 29: 379-381. [Medline] [CrossRef]

20. Suzuki, N., Matsunami, N., Kanamori, H., Ishida, N., Shimizu, A., Yaoita, Y., Nikaido, T. and Honjo, T. 1987. The human IL-2 receptor gene contains a positive regulatory element that functions in cultured cells and cell-free extracts. J. Biol. Chem. 262: 5079-5086. [Medline]

21. Valli, V. E. O. 2007. Bovine lymphoma. pp 199-201. In: Jubb, Kennedy, and Palmer's Pathology of Domestic Animals, vol. 3, 5th ed. (Maxie, M. G. ed.), Saunders Elsevier, Philadelphia.

22. Voss, S. D., Sondel, P. M. and Robb, R. J. 1992. Characterization of the interleukin 2 receptors (IL-2R) expressed on human natural killer cells activated in vitro by IL-2. J. Exp. Med. 176: 531-541. [Medline] [CrossRef]

23. Wu, J., Mao, Y., He, L., Wang, N., Wu, C., He, Q. and Skog, S. 2000. A new cell proliferating marker: cytosolic thymidine kinase as compared to proliferating cell nuclear antigen in patients with colorectal carcinoma. Anticancer Res. 20: 4815-4820. [Medline]

24. Yodoi, J., Uchiyama, T. and Maeda, M. 1983. T-cell growth factor receptor in adult T-cell leukemia. Blood 62: 509-511. [Medline]

25. Youn, H. Y., Goitsuka, R., Okuda, M., Watari, T., Tsujimoto, H. and Hasegawa, A. 1994. Two forms of the mb-1 gene transcript in cattle. J. Immunol. 153: 5127-5132. [Medline] 